\title{
Detection and characterization of fibropapilloma associated herpesvirus of marine turtles in Rio Grande do Sul, Brazil ${ }^{1}$
}

\author{
Carla R. Rodenbusch ${ }^{2 *}$, Laura L. Almeida ${ }^{2}$, Fernanda S. Marks², Michelli W. Ataíde ${ }^{3}$, \\ Marcelo M. Alievi ${ }^{3}$, Maurício Tavares ${ }^{4}$, Rosecler Alves Pereira ${ }^{5}$ and Cláudio W. Canal ${ }^{2}$
}

\begin{abstract}
Rodenbusch C.R., Almeida L.L., Marks F.S., Ataíde M.W., Alievi M.M., Tavares M., Pereira R.A. \& Canal C.W. 2012. Detection and characterization of fibropapilloma associated herpesvirus of marine turtles in Rio Grande do Sul, Brazil. Pesquisa Veterinária Brasileira 32(11):1179-1183. Laboratório de Virologia, Faculdade de Veterinária, Universidade Federal do Rio Grande do Sul, Av. Bento Gonçalves 9090, Porto Alegre, RS 91540-000, Brazil. E-mail: carlarodenbusch@yahoo.com.br

Fibropapillomatosis (FP) is a benign tumoral disease that affects sea turtles, hampering movement, sight and feeding, ultimately leading to death. In Brazil, the disease was described for the first time in 1986. Research suggests the involvement of a herpesvirus in association with environmental and genetic factors as causal agents of FP. The objective of the present study was to detect and characterize this herpesvirus in sea turtles living in the coast of state Rio Grande do Sul (RS), Brazil. From October 2008 to July 2010, 14 turtles were observed between the beaches of Torres and Tavares, of which 11 were green turtles (Chelonia mydas) and 3 were loggerhead turtles (Caretta caretta). All turtles were young and mean curved carapace length was $37.71 \pm 7.82 \mathrm{~cm}$, and varied from 31 to $55 \mathrm{~cm}$. Only one green turtle presented a $1 \mathrm{~cm}$, papillary, pigmented fibropapilloma. Skin and fibropapilloma samples were analyzed by conventional and real time PCR assays to detect and quantify herpesvirus. All skin samples were negative, though the fibropapilloma specimen was positive in both tests. Viral load was 9,917.04 copies of viral genome per milligram of tissue. The DNA fragment amplified from the fibropapilloma sample was sequenced and allocated in the Atlantic phylogeographic group. This study reports the first molecular characterization of herpesvirus associated with fibropapilloma in turtles from the coast of RS.
\end{abstract}

INDEX TERMS: Fibropapilloma, sea turtle, herpesvirus, Brazil.

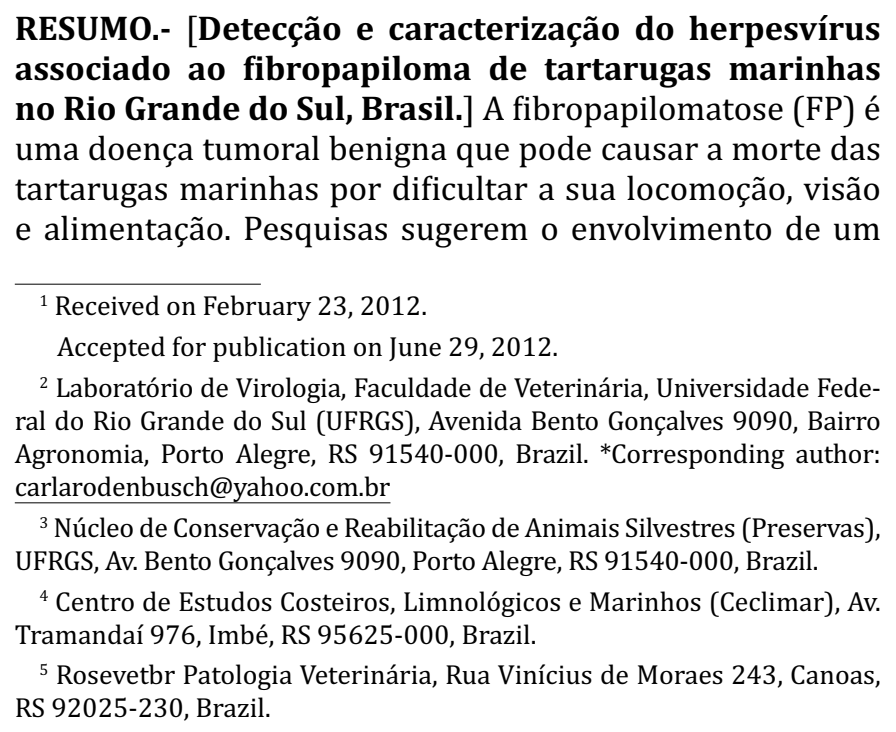

RESUMO.- [Detecção e caracterização do herpesvírus associado ao fibropapiloma de tartarugas marinhas no Rio Grande do Sul, Brasil.] A fibropapilomatose (FP) é uma doença tumoral benigna que pode causar a morte das tartarugas marinhas por dificultar a sua locomoção, visão e alimentação. Pesquisas sugerem o envolvimento de um

\footnotetext{
${ }^{1}$ Received on February 23, 2012.

Accepted for publication on June 29, 2012.

${ }^{2}$ Laboratório de Virologia, Faculdade de Veterinária, Universidade Federal do Rio Grande do Sul (UFRGS), Avenida Bento Gonçalves 9090, Bairro Agronomia, Porto Alegre, RS 91540-000, Brazil. *Corresponding author: carlarodenbusch@yahoo.com.br

${ }^{3}$ Núcleo de Conservação e Reabilitação de Animais Silvestres (Preservas), UFRGS, Av. Bento Gonçalves 9090, Porto Alegre, RS 91540-000, Brazil.

${ }^{4}$ Centro de Estudos Costeiros, Limnológicos e Marinhos (Ceclimar), Av. Tramandaí 976, Imbé, RS 95625-000, Brazil.

${ }^{5}$ Rosevetbr Patologia Veterinária, Rua Vinícius de Moraes 243, Canoas, RS 92025-230, Brazil.
}

herpesvirus em associação com fatores ambientais e genéticos como agentes causais da FP. No Brasil, foi descrita pela primeira vez em 1986.0 objetivo do presente trabalho foi detectar e caracterizar esse herpesvírus em tartarugas marinhas do litoral do Estado do Rio Grande do Sul (RS). De outubro de 2008 a julho de 2010, foram encontradas 14 tartarugas marinhas entre as praias de Torres e Tavares, das quais 11 eram tartarugas verdes (Chelonia mydas) e 3 eram tartarugas cabeçudas (Caretta caretta). Todas as tartarugas eram jovens e o comprimento curvilíneo de carapaça médio foi de $37,71 \pm 7,82 \mathrm{~cm}$, variando de 31 a $55 \mathrm{~cm}$. Apenas uma tartaruga verde apresentou um fibropapiloma de $1 \mathrm{~cm}$, pigmentado e de superfície papilar. Amostras de pele e do fibropapiloma foram submetidas a PCR convencional e PCR em tempo real para detecção e quantificação do herpesvírus. Todas as amostras de pele foram negativas e o fibropapiloma foi positivo em ambas as técnicas, apresentando uma carga viral de 9.917,04 cópias de genoma 
viral/mg de tecido. 0 fragmento de DNA amplificado na amostra de fibropapiloma foi sequenciado e revelou pertencer ao grupo filogeográfico do Atlântico. Essa é a primeira caracterização molecular do herpesvirus associado ao fibropapiloma em tartarugas do litoral do RS.

TERMOS DE INDEXAÇÃO: Fibropapiloma, tartaruga marinha, herpesvírus, Brasil.

\section{INTRODUCTION}

Fibropapillomatosis (FP) in sea turtles is an emerging disease, with high prevalence figures being reported from the 1980 's on (Herbst et al. 2004). It is characterized by one or multiple fibroepithelial growths whose surface is either smooth or rough, apart from the presence of fibromas in viscera (Kang et al. 2008). Tumors are benign, but interfere in movement, feeding and operation of organs, weakening the animal and even leading to death (Herbst 1994).

The first record of FP in the Brazilian coastline was made in 1986 (Baptistotte et al. 2005) and since then outbreaks have been frequently observed in feeding areas. Records indicate an increase in FP incidence: $3.2 \%$ in 1997, $10.8 \%$ in 1998, 10.9 in 1999 and 12.4\% in 2000 (Baptistotte 2007). Between 2000 and 2005, the average prevalence of FP in green turtles in Brazil was 15.41\% (1288/8359) with 36.94\% (181/490) in Ceará (CE), 31.43\% (33/105) in Rio Grande do Norte (RN), 18.46\% (12/65) in Sergipe (SE), $15.81 \%$ (211/1335) in Bahia (BA), 27.43\% (469/1710) in Espírito Santo (ES), 5.96\% (9/151) in Rio de Janeiro (RJ), $10.73 \%$ (371/3456) in São Paulo (SP) and 3.45\% (2/58) in Santa Catarina (SC) (Baptistotte 2007). In the same period, no tumor was recorded in turtles living in the oceanic islands of Fernando de Noronha and Atol das Rocas (Baptistotte 2007, Torezani et al. 2010) and there is no official record of FP in RS.

The pattern of spreading of FP is that of an infectious disease (Herbst et al. 1995). A herpesvirus has been identified in $100 \%$ of tumors induced by inoculation of tumor cell infiltrates (Ene et al. 2005) and 95\% of natural infections (Quackenbush et al. 2001). However, the disease seems have a multifactor character, since the presence of ectoparasites (Greenblatt et al. 2004), environmental pollution (Torezani et al. 2010, Santos et al. 2010), ingestion of macroalgae (Van Houtan et al. 2010) as well as water temperature (Herbst et al. 1995) seem to influence FP occurrence. The herpesvirus detected in fibropapillomas belongs to the family Herpesviridae, subfamily Alphaherpesvirinae, genus Scutavirus, and was called chelonid herpesvirus 5 (ChHV-5) (ICTV, 2011).

In their phylogenetic analysis of ChHV 5 variants Herbst et al. (2004) identified two major clades each with Atlantic and Pacific representatives. Analyzing glycoprotein B (Greenblatt et al., 2005), four groups of variants were described: the Atlantic (formed by sequences from Florida and Barbados), the Middle Pacific (Hawaii), the Western Pacific (Australia) and the Eastern Pacific (Costa Rica and California). Four phylogeographic groups were described: the Eastern Pacific (consisting of the samples from San Diego, Costa Rica and Mexico), the Western Atlantic/Eastern
Caribbean (Florida samples and Barbados), the Mid-west Pacific (Australia and Hawaii samples) and Atlantic (Gulf of Guinea and Puerto Rico samples) (Patricio et al. 2012).

The present study aimed to formalize the first record and characterization of ChHV-5 in turtles that live on the coast of Rio Grande do Sul (RS).

\section{MATERIALS AND METHODS}

\section{Turtles}

The 14 turtles used in this study were found beached or dead, between October 2008 and July 2010, between the beaches of Torres (31 $\left.11^{\prime} \mathrm{S}\right)$ and Tavares $\left(29^{\circ} 20^{\prime} \mathrm{S}\right)$ on the coast of RS. Beached turtles were sent to the Centro de Estudos Costeiros, Limnológicos e Marinhos (Ceclimar) for diagnosis and rehabilitation. Samples were collected under authorization number 19116-11, given by Instituto Chico Mendes para a Conservação da Biodiversidade, an organ of the Ministério do Meio Ambiente. When fibropapillomas were present, samples were collected from growths. In animals with no fibropapilloma, a fragment of neck skin was collected for analysis. All tumor or skin samples were analyzed individually. Collections were carried out using standard surgical instruments. Specimens were frozen at $-80^{\circ} \mathrm{C}$ upon processing.

\section{PCR amplification and genetic typing}

Tissues collected were macerated in a $10 \mathrm{mM}$ phosphate buffered saline (PBS) pH $7.4(0.05 \mathrm{~g} / 5 \mathrm{~mL})$. The suspension was clarified at $350 \times$ G for 10 min. DNA extraction was carried out using a $200-\mu \mathrm{L}$ aliquot of the supernatant, according to the method by Chomksinsky (1993).

A 2- $\mu \mathrm{L}$ DNA aliquot was submitted to PCR in a final $50-\mu \mathrm{L}$ volume using the specific primers for DNA polymerase of turtle herpesvirus, GTHV 2 (5'-GACACGCAGGCCAAAAAGCGA-3') and GTHV3 (5'-AGCATCATCCAGGCCCACAA-3'), described by Quackenbush et al. (2001). The conventional PCR reaction was conducted in $10 \mathrm{mM}$ Tris- $\mathrm{HCl}$ (pH 8.3), $2 \mathrm{mM} \mathrm{MgCl}_{2}, 50 \mathrm{mM} \mathrm{KCl}, 2.5 \%$ DMSO, $0.2 \mathrm{mM}$ each dNTP, $10 \mu \mathrm{M}$ each primer, and $2.5 \mathrm{U}$ Taq DNA polymerase (Ludwig Biotechnology Ltda). All samples were denaturated at $94^{\circ} \mathrm{C}$ for $5 \mathrm{~min}$ and then were amplified with 35 cycles $\left(94^{\circ} \mathrm{C}\right.$ for $30 \mathrm{~s}, 62^{\circ} \mathrm{C}$ for $30 \mathrm{~s}$, and $72^{\circ} \mathrm{C}$ for $30 \mathrm{~s}$ ) and then a 10 -min cycle at $72^{\circ} \mathrm{C}$ in a Veriti ${ }^{\mathrm{TM}}$ thermal cycler (Applied Biosystems), conform described by Quackenbush et al. (2001). From each amplification reaction, $5 \mu \mathrm{L}$ were electrophoresed in $2 \%$ agarose gels. The PCR products were 483-bp fragments and were purified using the kit GFX Purification (GE Healthcare, UK). Automated sequencing was carried out in an ABI-PRISM 3100 Genetic Analyzer automatic sequencer (Applied Biosystems) at the ACTGene Laboratory (Centro de Biotecnologia, UFRGS, Porto Alegre, Brazil) using the GTHV2/GTHV3 primers.

Subsequently, the nucleotide sequences were processed using the BioEdit program and aligned with Clustal W (Thompson et al. 2002), and the resulting sequences were submitted to GenBank (http://www.ncbi.nlm.nih.gov). Kimura 2-parameter pairwise distances (Kimura 1980), calculated for the different nucleotide sequences detected in Brazil, were used to construct a phylogenetic unrooted tree by using the neighbor joining distance methods in the Molecular Evolutionary Genetics Analysis software MEGA 4 (Tamura et al. 2007).The following parameters were used for multiple alignment: gap opening penalty $=3$, gap extension penalty $=1.8$, and keeping the default parameters (Patricio et al. 2012). The statistical confidence of the tree topologies was performed by 1000 bootstrap replications using the same software. 


\section{Real time quantitative PCR}

Samples were also submitted to real time PCR to determine the number of copies of viral DNA. The primers ("turtle 5'pol" - 5'ACTGGCTGGCACTCAGGAAA3' and "turtle 3'pol" - 5'CAGCTGCTGCTTGTCCAAAA3') and probe (5'-[6FAM]-CGATGAAAACCGCACCGAGC GA[TAMRA]-3') used were previously described by Quackenbush et al. (2001), which amplify an 86 bp fragment of the gene of the viral DNA polymerase. The reaction was conducted in a $25 \mu \mathrm{L}$ final volume formed by $2 \mu \mathrm{L}$ DNA, $5 \mu \mathrm{M}$ each primer and $10 \mu \mathrm{M}$ probe in $12.5 \mu \mathrm{L}$ Platinum Quantitative PCR Supermix UDG (Invitrogen). Reaction mixtures were heated to $50^{\circ} \mathrm{C}$ for $2 \mathrm{~min}$ and to $95^{\circ} \mathrm{C}$ for 10 min to activate Taq polymerase followed by 40 cycles of $15 \mathrm{~s}$ at $95^{\circ} \mathrm{C}$ and $1 \mathrm{~min}$ at $62^{\circ} \mathrm{C}$ in a thermal cycler StepOne ${ }^{\mathrm{TM}}$ Real-Time PCR (Applied Biosystems) conform described by Quackenbush et al. (2001). The standard curves used in reactions were log-transformed serial dilutions of the GTHV DNA pol, constructed by inserting a 483-bp fragment of the DNA polymerase gene of the herpesvirus in a vector, following the instructions provided by manufacturer of the kit TOPO TA Cloning ${ }^{\mathrm{TM}}$ (Invitrogen) (Quackenbush et al. 2001).

\section{Histological analysis}

Sections of tumors were fixed in formalin 10\%. After 5 days, specimens were dehydrated, clarified, embedded in paraffin, cut into $5 \mu \mathrm{m}$ slices and stained according to the hematoxylin-eosin method.

\section{RESULTS}

Between October 2008 and July 2010, 14 turtles were observed, of which 11 were green turtles (Chelonia mydas) and 3 were loggerhead turtles (Caretta caretta) (Table 1). Only one green turtle presented a fibropapilloma, which measured $1 \mathrm{~cm}$, in the pelvic region (Fig.1). The tumor surface had a papillary aspect, and was pigmented. All turtles were young, of undetermined sex, and curved carapace length (CCL) varying between 31 and $55 \mathrm{~cm}$ (mean: $37.71 \pm 7.82 \mathrm{~cm})$.

All skin specimens were negative for the herpesvirus in both conventional and real time PCR. However, the fibropapilloma sample was positive for the herpesvirus in PCR, and detected a viral load of 9,917.04 copies of viral genome per milligram of tissue. The number of copies of the genome was obtained by multiplying the value obtained by 7.5 , the number of dilutions used in the DNA extraction routine. The correlation coefficient of the standard curve was $>0.9$.

Table 1. Detection of herpesvirus in fibropapilloma and skin samples from sea turtles in Rio Grande do Sul, Brazil

\begin{tabular}{llcccc}
\hline Number & Species & CCL $(\mathrm{cm})^{*}$ & Sample & PCR & Real time PCR \\
\hline $001 / 08$ & C. mydas & 54.0 & Fibropapilloma & Positive & $9,917.04$ \\
$002 / 08$ & C. caretta & 35.0 & Skin & Negative & Negative \\
$001 / 09$ & C. caretta & 32.5 & Skin & Negative & Negative \\
$001 / 10$ & C. mydas & 31.5 & Skin & Negative & Negative \\
$002 / 10$ & C. mydas & 55.0 & Skin & Negative & Negative \\
$003 / 10$ & C. caretta & 32.0 & Skin & Negative & Negative \\
$004 / 10$ & C. mydas & 42.0 & Skin & Negative & Negative \\
$005 / 10$ & C. mydas & 31.0 & Skin & Negative & Negative \\
$006 / 10$ & C. mydas & 35.0 & Skin & Negative & Negative \\
$007 / 10$ & C. mydas & 32.0 & Skin & Negative & Negative \\
$008 / 10$ & C. mydas & 36.0 & Skin & Negative & Negative \\
$009 / 10$ & C. mydas & 38.0 & Skin & Negative & Negative \\
$111 / 10$ & C. mydas & 40.0 & Skin & Negative & Negative \\
$112 / 10$ & C. mydas & 34.0 & Skin & Negative & Negative \\
\hline
\end{tabular}

*CCL= curved carapace length, ${ }^{* *}$ Copies of viral genome $/ \mathrm{mg}$.

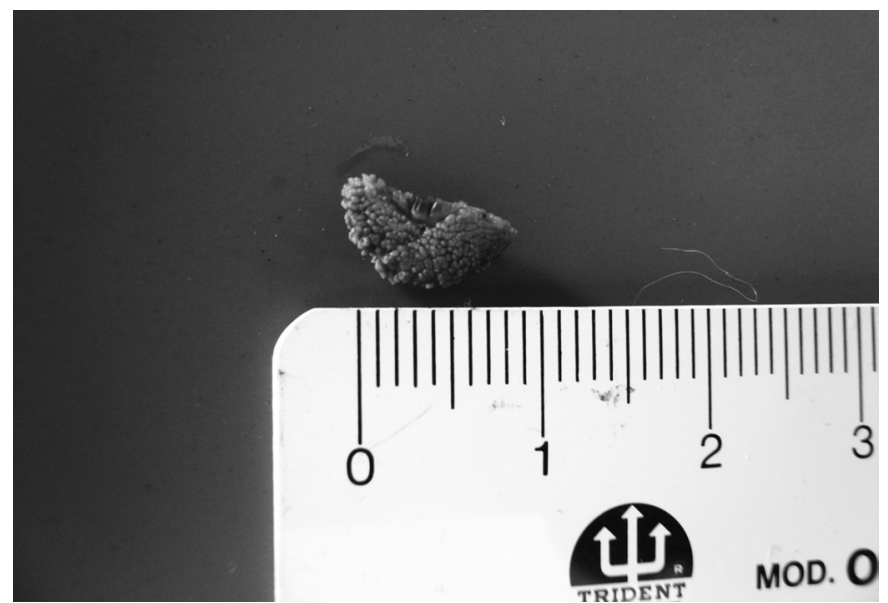

Fig.1. Fibropapilloma with papillary, pigmented aspect.

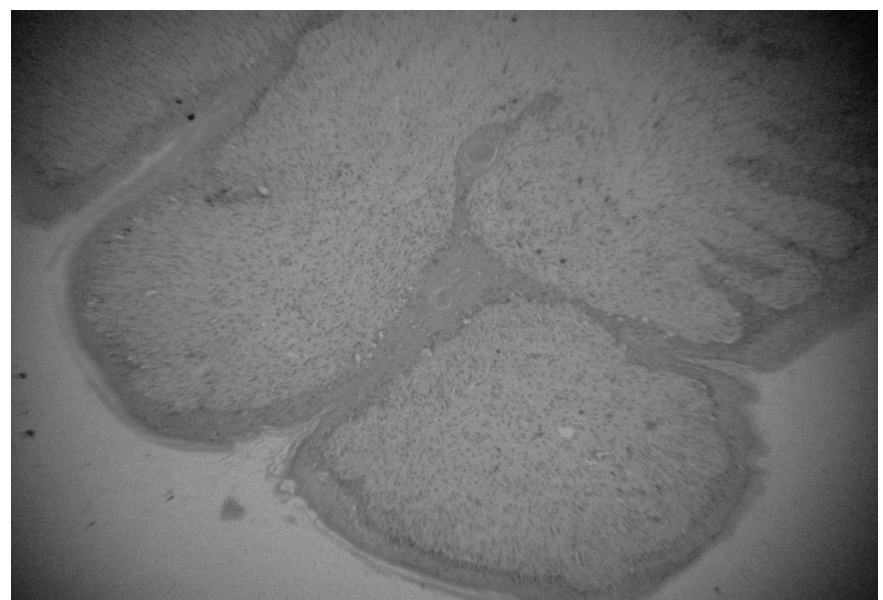

Fig.2. Histopathological section of fibropapilloma showing a papillary pattern. Hematoxylin-eosin, 5x.

The histopathology analysis revealed a papillary pattern, with the presence of melanocytes, epithelial hyperplasia, hyperkeratosis and a nuclear halo, apart from moderate stromal hyperplasia and dyskaryosis (Fig.2).

The amino acid sequence of the sample of fibropapilloma was confirmed to be a fragment of the gene of DNA polymerase of ChHV-5 by alignment with sequences deposited in GenBank using the BLAST (Basic Local Alignment Search Tool). The sequence was deposited under the accession number JN938584.

\section{DISCUSSION}

This is the first molecular characterization of ChHV-5 in turtles in RS. In Brazil, DNA of herpesvirus had been detected by PCR in samples of fibropapillomas and blood collected in sea turtles in the state of São Paulo (Monezi et al. 2006).

All five sea turtle species that occur in Brazil are observed in the country's southernmost seawaters: Chelonia mydas, Caretta caretta, Dermochelys coriacea, Lepidochelys olivacea, and Eretmochelys imbricata (Pinedo et al. 1996, Marcovaldi \& Marcovaldi 1999). The first three species mentioned are often observed beached on the shores of RS (Bugoni et al. 2001) and two were found during the study period. 
Juvenile sea turtles use the coast of RS for feeding and developing, especially in summer and spring in the southern hemisphere (Soto \& Beheregaray 1997). The negative result of PCR in the skin samples of turtles without fibropapillomatosis shows that they are not carriers of the virus. The viral load detected in tumor collected was 9,917.04 copies per mg tumor. This value suggests that ChHV 5 plays a dominant role in maintenance and introduction of the tumor state.

Comparing $6801 \mathrm{bp}$ of the viral genome (Herbst et al. 2004), 5 viral variants were found in 25 turtles of 3 species (C. mydas, C. caretta and L. kempii) and were named Florida A, B, C and D and Hawaiian (HA). Variants Florida A, B and $C$ are nearly identical. Variant $D$, which was isolated from the loggerhead turtle (Caretta caretta), differs by $5.6 \%$ from the other variants, whereas the HA variant differs from the Florida variants A, B and C by only $2.2 \%$ (Herbst et al. 2004). The same pattern of variants was maintained within the 483-bp sequence of the DNA polymerase (Herbst et al., 2004; Patricio et al. 2012) that was analyzed in the present study. Sequencing of the fibropapilloma specimens collected in RS was introduced into phylogeographic groups described (Patricio et al., 2012), and was allocated in Atlantic group (Fig.3). There is no record of turtle migration between Brazil and Puerto Rico, but telemetry (Hays et al. 2001) and population genetic (Naro-Maciel et al. 2007) studies revealed a connection between turtles from Brazil and Ascencion Island. The study conducted by Naro-Maciel et al. (2007) also indicates the occurrence of haplotypes of turtles from Atol das Rocas, Trindade Island, Ascencion Island, Africa, Mexico, Costa Rica and Surinam in turtles observed in Almofala (CE) and Ubatuba (SP) in the Brazilian coast. The analysis of more sequences of fibropapilloma samples from the Brazilian coast should show the variants circulating in Brazil and whether these variants are related to migration.

Histopathology showed the presence of epithelial hyperplasia and nuclear halos as described by Matushima et al. (2001) in fibropapillomas from São Paulo state. The proliferative cutaneous lesion of the green turtle from this report was similar to the previously described in fibropapillomas of green turtles from Florida (Lucke 1938, Smith $\&$ Coates 1938).

Curved carapace length varied between 31 and $55 \mathrm{~cm}$ and the turtle who presented the fibropapilloma was $54 \mathrm{~cm}$ CCL. FP appears to affect certain age and size classes of turtles more than others. FP is rare (0-12\%) among nesting adult females and lesions tend to be focal and mild, although these are underestimates of the true prevalence in the adult population (Herbst, 1994). In Hawaiian feeding ground sites, intermediate-sized turtles $(40-90 \mathrm{~cm}$ carapace length) were most commonly and most severely affected (Balazs 1991). Turtles with tumors sampled in four states were between 33 and $76 \mathrm{~cm}$ in carapace length. In Brazil, the higher frequency of tumors in green turtles is displayed between 30 and $80 \mathrm{~cm}$ carapace length (Baptistotte 2007). The absence of the FP in animals with less than $30 \mathrm{~cm}$ could be explained by lack of time for the onset of the disease. The low prevalence above $8 \mathrm{~cm}$ could be explained in two

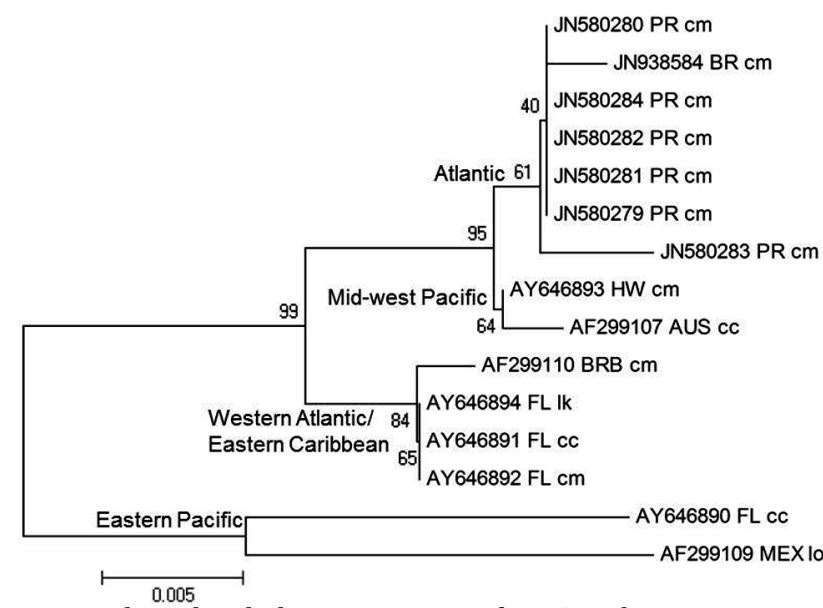

Fig.3. Nucleotide phylogenetic tree of DNA polymerase gene of the ChHV 5 using the neighbor joining distances method, with 1000 bootstrap replication. Sequences were generated in this study or retrieved from GenBank. CR; Costa Rica (Pacific coast), BR; (Brazil), FL; (Florida), HW; (Hawaii), AUS; Australia (Pacific coast), BRB; Barbados, MEX; Mexico (Pacific coast), PR; Puerto Rico. cm; Chelonia mydas, cc; Caretta caretta, lo; Lepidochelys olivacea, lk; Lepidochelys kempi.

ways: 1) the disease would be self-limiting and at this stage of life individuals would have been cured due to an increased resistance conferred by age, 2) the prevalence would result in the mortality of the turtles before they reach a larger size. Foley et al. (2005) suggested a combination of both options.

There is no record of the prevalence of fibropapillomatosis on sea turtles in the RS and few of anecdotal information circulates specially among marine biologists and veterinarians of wild animal regarding the presence of these disease in turtles found of the coast of the RS. The result of this study serves as a warning to the disease in the RS, since a high viral load was found in one lesion.

Acknowledgements.- To ICMBio and IBAMA for the license to conduct this research with turtles, to CECLIMAR for the turtles analyzed and to CNPq for the doctorship grant and financial support.

\section{REFERENCES}

Balazs G.H. 1991. Current status of fibropapillomas in the Hawaiian green turtles, Chelonia mydas. In: Balazs G.H. \& Polley S.G. (Eds), Research Plan for Marine Turtle Fibroapilloma. U.S. Department of Commerce, National Oceanographic and Atmospheric Administration, National Marine Fisheries Service. NOAA-TM-NMFS-SWFSC 156:47-57.

Baptistotte C., Moreira L.M.P., Becker J.H., Lopes G., Castilhos J.C., Lima E., Grossman A., Wanderlinde J. \& Marcovaldi M.A. 2005. Frequency of occurrence of tumors in green turtles, Chelonia mydas record by project TAMAR-IBAMA in Brazilian coast from years 2000 to 2004. XIX Annual Meeting of the Society for Conservation Biology. Brasília, DF, p.14-15. (Abstract)

Baptistotte C. 2007. Caracterização especial e temporal da fibropapilomatose em tartarugas marinhas da costa brasileira. Tese de Doutorado, Escola Superior de Agricultura Luiz de Queiroz, Universidade de São Paulo, Piracicaba. 63p.

Bugoni L., Krause L. \& Petry M.V. 2001. Marine debris and human impacts on sea turtles in southern Brazil. Marine Pollution Bull. 42:1330-1334.

Chomkczynski P.A. 1993. A reagent for the single-step simultaneous isolation of RNA, DNA and protein from the cell and tissues samples. Biotechniques 15:532-537. 
Ene A., Lemaire S., Rose C., Schaff S., Moretti R., Lenz J. \& Herbst L.H. 2005. Distribution of chelonid fibropapillomatosis-associates herpesvirus variants in Florida: molecular genetic evidence for infection of turtles following recruitment to neritic developmental habitats. J. Wildl. Dis. 41(3):489-497.

Foley A.M., Schroeder B.A., Redlow A.E., Fick-Child K.J. \& Teas W.G. 2005. Fibropapillomatosis in stranded green turtles (Chelonia mydas) from the eastern United States (1980-98): trends and associations with environmental factors. J. Wildl. Dis. 41(1):29-41.

Greenblatt R.J., Work T.M., Balazs G.H., Sutton C.A., Casey R.N. \& Casey J.W. 2004. The Ozobranchus leech is a candidate mechanical vector for the fibropapilloma-associated turtle herpesvirus found latently infecting skin tumors on Hawaiian green turtle (Chelonia mydas). Virology 321:101-110.

Greenblatt R.J., Quackenbush S.L., Casey R.N., Rovnak J., Balazs G.H., Work T.M., Casey J.W. \& Sutton C.A. 2005. Genomic variation of the fibropapilloma-associated marine turtle herpesvirus across seven geographic areas and three host species. J. Virology 72(2):1125-1132.

Hays G.C., Dray M., Quaife T., Smyth T.J., Mironet N.C., Luschi P., Papi F. \& Barnsley M.J. 2001. Movement of migrating green turtles in relation to AVHRR derived sea surface temperature. Int. J. Remote Sensing 22 (8):1403-1411.

Herbst L.H. 1994. Fibropapillomatosis of marine turtles. Annu. Rev. Fish Dis. 4:389-425.

Herbst L.H., Jacobson E.R., Moretti R., Brown T., Sundberg J.P. \& Klein P.A. 1995. Experimental transmission of green turtle fibropapillomatosis using cell-free tumor extract. Diseases of Aquatic Organisms 22:1-12.

Herbst L., Ene A., Su M., Desalle R. \& Lenz J. 2004. Tumor outbreaks in marine turtles are not due to recent herpesvirus mutations. Current Biology 14(17):697-699.

ICTV 2011. Virus Taxonomy: 2011 Release. International Committee on Taxonomy of Viruses. <http://www.ictvonline.org/virusTaxonomy.asp? version=2011 > Accessed March 7, 2012.

Kang K.I., Torres-Velez F.J., Zhang J., Moore P.A., Moore P.D., Rivera S. \& Brown C.C. 2008. Localization of fibropapilloma-associated turtle herpesvirus in Green Turtle (Chelonia mydas) by in-situ hybridization. J. Comp. Pathol. 139:218-225.

Kimura M. 1980. A simple method for estimating evolutionary rates of base substitutions through comparative studies of nucleotide sequences. J. Mol. Evol. 16:111-120.

Lucke B. 1938. Studies on tumors in cold-blooded vertebrates. Annual Reports of the Tortugas Laboratory, Carnegie Institute of Washington 38:92-94.

Marcovaldi M.A. \& Marcovaldi G.G. 1999. Marine turtles of Brazil: the history and structure of Projeto TAMAR-IBAMA. Biological Conservation 91:35-41.

Matushima E.R., Longatto Filho A., Di Loretto C., Kanamura C.T., Sinhorini I.L., Gallo B. \& Baptistotte C. 2001. Cutaneous papillomas of Green tur- tles: a morphological, ultra-structural and immunohistochemical study in Brazilian specimens. Braz. J. Vet. Res. Anim. Sci. 38(2):51-54.

Monezi T.A. \& Muller N.M.G., Matushima E.R., Rossi S., Rondon M. \& Mehnert D.U. 2006. Detecção de herpesvírus em tumor e sangue de tartarugas marinhas da espécie Chelonia mydas mantidas na base do Projeto TAMAR, Ubatuba/SP, nos anos de 2005 e 2006. Anais X Congresso e XV Encontro da Associação Brasileira de Veterinários de Animais Selvagens, São Pedro, SP, p.21. (Abstract)

Naro-Maciel E., Becker J.H., Lima H.S.M., Marcovaldi M.A. \& Desalle R. 2007. Testing dispersal hypotheses in foraging Green sea turtles (Chelonia mydas) of Brazil. J. Heredity 98(1):29-39.

Patricio, A.R., Herbst L.H., Duarte A., Vélez-Zuazo X., Santos Loureiro N., Pereira N., Tavares L. \& Toranzos G.A. 2012. Global phylogeography and evolution of chelonid fibropapilloma-associated herpesvírus. J. Gen. Virology. 93 (Pt 5):1035-1045.

Pinedo M.C., Capitoli R.R., Barreto A.S. \& Andrade A. 1996. Occurrence and feeding of sea turtles in southern Brazil. Proc. $16^{\text {th }}$ Annual Symposium on Sea Turtle Conservation and Biology, Hilton Head, SC, USA, p.51.

Quackenbush S.L., Work T.M., Balazs G.H., Casey R.N., Rovnak J., Chaves A., Dutoit L., Baines J.D., Parrish C.R., Bowser P.R. \& Casey J.W. 1998. Three closely related herpesviruses are associated with fibropapillomatosis in marine turtles. Virology 246(2):392-399.

Quackenbush S.L., Casey R.N., Murcek R.J., Paul T.A., Work T.M., Limpus C.J., Chaves A., Dutoit L., Perez J.V., Aguirre A.A., Spraker T.R., Horrocks J.A., Horrocks J.A., Vermeer L.A., Balazs G.H. \& Casey J.W. 2001. Quantitative analysis of herpesvirus sequences from normal tissue and fibropapillomas of marine turtles with real-time PCR. Virology 287:105-111.

Santos R.G., Martins A.S., Torezani E., Baptistotte C., Farias J.N., Horta P.A., Work T.M. \& Balazs G.H. 2010. Relationship between fibropapilomatosis and environmental quality: A case with Chelonia mydas off Brazil. Disease of Aquatic Organism 89:87-95.

Smith G.M. \& Coates C.W. 1938. Fibroepithelial growths of the skin in large marine turtles, Chelonia mydas (Linnaeus). Zoologica 23:93-96.

Soto J.M.R. \& Beheregaray R.C.P. 1997. Chelonia mydas in the northern region of the Patos lagoon, South Brazil. Marine Turtle Newsletter 77:1011.

Tamura K., Dudley J., Masatoshi N. \& Kumar S. 2007. MEGA4: Molecular Evolutionary Genetics Analysis (MEGA) Software Version 4.0. Mol. Biol. Evol. 24(8):1596-1599.

Thompson J.D., Higgings D.G. \& Gibson T.J. 1994. CLUSTAL W: improving the sensitivity of progressive multiple sequence alignment through sequence weighting, position-specific gap penalties and weight matrix choice. Nucl. Acids Res. 22:4673-4680.

Torezani E., Baptistotte C., Mendes S.L. \& Barat P.C.R. 2010. Juvenile green turtles (Chelonia mydas) in the effluent discharge channel of a steel plant, Espirito Santo, Brazil, 2000-2006. J. Marine Biol. Assoc. UK 90(2):233246.

Van Houtan K.S., Hargrove S.K. \& Balazs G.H. 2010. Land use, macroalgae, and a tumor-forming disease in marine turtles. PLoS ONE 5(9):e12900. 